\title{
STUDY OF COMPETITIVE ABILITY OF SOME HYBRIDS OF MAIZE WITH ASSOCIATED WEED
}

\author{
F.S.Abd-El-Samie ; Ekram. A.Megawer ;S.M.Emam and M.Y.Hussein.
}

Agron.Dept., Fac. Agric . Fayoum Univrsity, Egypt .

\begin{abstract}
:
Two field trials were performed at Tamiya Experimental Station, Fayoum Governorate Egypt, during 2012 and 2013 seasons, to study the competitive ability of some maize hybrids in associated weeds by modification of crop density. The experiment included: Three hill distances (25,30and 35 cm apart) on one side of ridge at approximately 28000,23333 and 20000 plants / fed ,Three weed control treatments, one hand hoeing ,hand hoeing twice and the unweeded (control) and Three maize hybrids, i.e. , T.W.C.310, T.W.C.1100 and T.W.C. Nefertiti 3.

Results showed that all weeded treatments significantly depressed weed growth comparing to the unweeded one application of hoeing caused significant increases in plant height, ear height ,number of ear /plant, all ear characters, and grain yield / feddan . Moreover, two hoeing superiored one hoeing in all characters. Each increases in hill distances resulted in increasing total weed dry weight, ear height, number of ear /plant ,ear length ,ear diameter, grain number / ear ,ear weight, grain weight /ear , 100- grain weight and grain yield / feddan .Neffertiti 3 surpassed other hybrids in all grain characters and grain yield / feddan .While T W C 1100 recorded the lowest values.
\end{abstract}

Key words : Maize, Hill distances, weed, Hand hoeing, yield.

INTRODUCTION :

Maize ( Zea mays L.) is one of the most important strategic cereal crops in Egypt and the world. Egypt ranks fourth in the world with respect of average productivity after USA, France and Italy. Since, the total cultivated area of maize crop in Egypt reached about 1.786 million feddan in 2014 season, producing 5.8 million ton, thus the average production of maize is 23.2 ardab / fed. Maize plant is high and strong, but it is sensitive to weed. Also weed control in maize fields is an important cultural practice for raising its grain yield. We also believe that crop competition is considered one of the cheapest and most available weed control methods to farmers.

Poole and Gill, 1987,mentioned that modification of crop density may reduce the competitive effect of weeds. In this regard, closer planting giving higher plant population have a competitive advantage over weeds as stated by Abd-El-Samie,2001, who indicated that both weed control and maize grain yield were improved by increasing plant density from 20000 to 30000 plants / fed. El-Metwally et al.,2012, reported that narrowing the spacing between maize plants from $30 \mathrm{~cm}$ to $17 \mathrm{~cm}$ (35000 plants / fed) caused a significant reduction $(21 \%)$ in the total weed dry weight . Amara et al (2015) showed

Fayoum J. Agric. Res. \& Dev., Vol. 31, No.2, July, 2017 
that the minimum dry weight of weeds in maize was observed in hand weeding followed by Nicosulfuron at $0.09 \mathrm{~kg}$ ha-1. However, AbdEI-Samie, (2000) reported that hand hoeing twice at 21 and 35 days after sowing was the most effective treatment against weeds in maize, being caused 73.69 and 71.88 $\%$ reduction in fresh and dry weight of weeds, respectively, comparing with no weed control . AbdEl-Samie, (2001) studied the efficiency of five chemical and mechanical weed control treatments in maize. He found that all weeded treatments significantly depressed weed growth comparing to the unweeded one. The highest control values were achived by hand hoeing which caused 73.69 and $71.88 \%$ reduction in fresh and dry weight weeds, respectively. However, El- Metwally et al .,2012 found that uncontrolling weeds caused a significant reduction in the grain yield by $29.7 \%$ compared to hoeing treatment.

The recent studies confirmed that maize hybrids significantly differed in its productivity ( Aryannia et al.2013, Atta,2014, Farnia and Mansouri 2014 and Kandil 2014).

The present investigation was designed to study the influence of handhoeing and plant spacing on three maize hybrids and associated weeds .

\section{MATERIALS AND METHODS:}

Two field experiments were conducted at Tamiya experiment station Agric.Res.center (A.R.C ), Fayoum Governorate Egypt during 2012 and 2013 summer seasons. This investigation aimed to study the competitive ability of some hybrids of maize with associated weed. The soil texture was clay loam with organic matter 1.68 and $1.72 \%$, EC of 4.00 and $3.96, \mathrm{PH}$ values 8.12 and $8.20, \mathrm{CaCo}_{3}$ of 5.18 and $5.14 \%$ and available $\mathrm{N}$ ppm 8.0 and 8.2 ,in the first and second season ,respectively Each experiment included 27 treatments arranged in a split split plot design with four replicates. The treatments were the combinations of :

1. Three plant populations ( allocated in the main plots ), i.e $28000\left(\mathrm{P}_{1}\right)$, $23333\left(\mathrm{P}_{2}\right)$ and $20000\left(\mathrm{P}_{3}\right)$ plants per feddan obtained from planting at 25,30 and $35 \mathrm{~cm}$ between plants, respectively, on one side of ridges, $60 \mathrm{~cm}$ apart .

2. Three weed control treatments ( laid out in the sub-plot), i.e. hand hoeing once(W1), hand hoeing twice (W2) and unwedded (control) treatment (W3). 3.Three maize hybrids (arranged in the sub-sub plots), i.e.T.W.C.310 (H1),T.W.C.1100 (H2) and Nefertiti 3 (H3) .

Grains of hybrids maize (Zea mays, L.) were sown on 17 and 15 of April in 2012 and 2013 seasons, respectively, after follow in both seasons . After 21 days from sowing, plants were thinned to one plant per hill . N fertilizer (ammonium nitrate $33.5 \% \mathrm{~N}$ ) at a rate of $110 \mathrm{~kg} /$ feddan, $\mathrm{P}$ fertilizer (calcium super phosphate $15.5 \% \mathrm{P}_{2} \mathrm{O}_{5}$ ) at a rate $23.25 \mathrm{~kg} \mathrm{P}_{2} \mathrm{O}_{5} /$ feddan and $\mathrm{K}$ fertilizer (Potassium sulphate $48 \% \mathrm{~K}_{2} \mathrm{O}$ ) at a rate of $24 \mathrm{~kg} \mathrm{~K}_{2} \mathrm{O}$ / feddan were applied .Phosphorus and potassium were added during seed bed preparation, while nitrogen was applied in two equal portions before first and

Fayoum J. Agric. Res. \& Dev., Vol. 31, No.2, July, 2017 
STUDY OF COMPETITIVE ABILITY OF SOME HYBRIDS

second irrigation, respectively. Other cultural practices of growing maize plants were done as recommended.

\section{Data recorded:}

\section{Weeds:}

Weeds were hand pulled from the middle ridge of each sub-sub -plot at 60 days after sowing and calculated to gram per square meter. The total dry weight of weeds after drying at $70^{\circ} \mathrm{C}$ for 48 hours weight were recorded .

\section{Maize :}

At harvest, a random sample of ten guarded plants were taken from each sub-sub- plots to estimate plant and ear height, ear characters (length, diameter, no. of rows, no. of grains/ear, ear weight and weight of grains ) ,100- grain weight and shelling \% . plants of each experimental unit were harvested and grain yield of maize (ardab/feddan)was calculated on 15.5 $\%$ moisture basis.

All collected data were subjected to Statistical analysis. Mean were compared at .05 probability levels by least significant difference test (LSD) as explained by (Gomez And Gomez 1983).

\section{Results and Discussion:}

1. Weeds: Data presented in Table (1) indicated that there was a significant reduction in total weed dry weight with the increase of the plant population in both seasons . Narrowing the spacing between maize plants from 35 to $25 \mathrm{~cm}$ caused a significant reduction in the total weed dry weight in both seasons . These results stand in harmony with those recorded by El- Metwally, et al (2012) they found that narrowing the spacing between maize plants from 30 $\mathrm{cm}$ to $17 \mathrm{~cm}$ caused a significant reduction $(21 \%)$ in the total weed dry weight . Results indicated that weed growth was markedly inhibited with weeding than without, application of hand- hoeing significantly depressed growth of weeds over the unweeded control. These results are in complete agreement with those reported by Abd-El-Samie (2000). However two hoeings surpassed one hoeing in this respect.. this may de due to that repeating hoeing means elimination more weeds throughout longer period than when applied once .On the other hand, the tested hy had different competitive abilities against the associated weeds. TWC1100 plots contained less total weed growth by 6.6 and $21.6 \%$ than Nefertiti 3 and T.W.C.310 in the first season and by 9.8 and $21.3 \%$ in the second season, respectively.

Interaction effects of plant population and weed control treatments were significant for dry weight of weeds at 60 days after sowing, the lowest dry weight of weeds resulted from hand hoeing twice at the plant spacing of $25 \mathrm{~cm}$. These results are in harmony with those obtained by Abouziena, et al., (2008). Results revealed a significant effect of the interaction between maize varieties and weed control treatments, on dry weight of weeds at 60 days after sowing in both seasons. The lowest weight of dry weight of weed was obtained from sowing hybrid maize TWC 1100) with hand -hoeing twice

Fayoum J. Agric. Res. \& Dev., Vol. 31, No.2, July, 2017 
F.S.Abd-El-Samie., et al.,

Table (1) : Effect of plant population and weed control treatments on total dry weight of weed and grain yield / fed. of some maize hybrids in 2012 and 2013 seasons.

\begin{tabular}{|c|c|c|c|c|}
\hline Treatment Characters & $\begin{array}{c}\text { Total dry weight of weed } \\
\text { (g) }\end{array}$ & \multicolumn{2}{c|}{ Grain yield (ardab/ fed.) } \\
\hline Season & $\mathbf{2 0 1 2}$ & $\mathbf{2 0 1 3}$ & $\mathbf{2 0 1 2}$ & $\mathbf{2 0 1 3}$ \\
\hline Plant population : & 72.44 & 67.37 & 9.49 & 9.19 \\
\hline 28000 plants/ fed. & 107.56 & 100.74 & 12.10 & 12.64 \\
\hline 23333 plants / fed. & 126.37 & 124.56 & 11.50 & 10.70 \\
\hline 20000 plants / fed. & 6.30 & 8.25 & 1.841 & 0.169 \\
\hline LSD & 90.85 & 85.00 & 10.88 & 11.25 \\
\hline Weed Control : & 25.04 & 23.74 & 11.97 & 13.25 \\
\hline Hoeing (one) & 190.48 & 183.93 & 7.71 & 8.55 \\
\hline Hoeing (two) & 3.23 & 4.82 & 1.453 & 0.114 \\
\hline Unweeded & 116.81 & 110.07 & 9.33 & 10.07 \\
\hline LSD & 91.56 & 86.59 & 10.20 & 10.91 \\
\hline Maize Hybrids : & 98.00 & 96.00 & 11.03 & 11.55 \\
\hline TWC 310 & 3.33 & 4.23 & 1.649 & 0.097 \\
\hline TWC 1100 & 6.80 & 9.35 & N.S & 0.206 \\
\hline TWC Nefertiti 3 & 6.92 & 8.96 & N.S & 0.192 \\
\hline LSD & 5.54 & 7.42 & N.S & 0.173 \\
\hline LSD 5 \% interaction : & 10.23 & 13.48 & N.S & 0.305 \\
\hline P $\times$ W
\end{tabular}

\section{Maize characters:}

Data in Table (2) showed that plant height of maize plant was not statistically influenced by plant population in the first season. While plant height of maize plant was significantly decreased by increasing plant population up to 28000 plants/ feddan in the second season. However ear height as well as number of ear / plant were decreased by increasing plant population from 20 to 28 thousand plants / feddan in both seasons.

Fayoum J. Agric. Res. \& Dev., Vol. 31, No.2, July, 2017 
STUDY OF COMPETITIVE ABILITY OF SOME HYBRIDS

Table (2) : Effect of plant population and weed control treatments on some growth characters of some maize hybrids in 2012 and 2013 seasons.

\begin{tabular}{|c|c|c|c|c|c|c|}
\hline \multirow{2}{*}{$\begin{array}{ll}\text { Treatment } & \text { Characters } \\
\text { Season }\end{array}$} & \multicolumn{2}{|c|}{ Plant height (cm) } & \multicolumn{2}{|c|}{ Ear height (cm) } & \multicolumn{2}{|c|}{$\begin{array}{c}\text { Number of ear / } \\
\text { plant }\end{array}$} \\
\hline & 2012 & 2013 & 2012 & 2013 & 2012 & 2013 \\
\hline \multicolumn{7}{|c|}{ Plant Population : } \\
\hline 28000 plants/ fed. & 170.0 & 161.7 & 70.7 & 59.8 & 1.03 & 1.07 \\
\hline 23333 plants / fed. & 177.9 & 181.3 & 73.3 & 77.4 & 1.16 & 1.19 \\
\hline 20000 plants / fed. & 175.3 & 202.3 & 76.4 & 86.1 & 1.22 & 1.31 \\
\hline LSD & N.S & 2.10 & 0.64 & 0.92 & 0.05 & 0.05 \\
\hline \multicolumn{7}{|c|}{ Weed Control : } \\
\hline Hoeing (one) & 174.6 & 180.9 & 73.9 & 75.3 & 1.16 & 1.21 \\
\hline Hoeing (two) & 180.4 & 195.6 & 76.7 & 81.8 & 1.20 & 1.27 \\
\hline Unweeded & 168.1 & 168.8 & 69.8 & 66.2 & 1.05 & 1.09 \\
\hline LSD & 2.92 & 1.70 & 0.96 & 1.00 & 0.04 & 0.04 \\
\hline \multicolumn{7}{|c|}{ Maize hybrids : } \\
\hline TWC 310 & 179.4 & 183.4 & 76.9 & 74.9 & 1.57 & 1.37 \\
\hline TWC 1100 & 167.8 & 175.2 & 68.4 & 69.8 & 1.17 & 1.22 \\
\hline TWC Nefertiti 3 & 176.0 & 186.7 & 75.1 & 78.6 & 1.10 & 1.11 \\
\hline LSD & 5.08 & 0.88 & 0.53 & 94.00 & 0.05 & 0.04 \\
\hline \multicolumn{7}{|c|}{ LSD $5 \%$ interaction : } \\
\hline $\mathrm{P} \times \mathrm{W}$ & N.S & 2.84 & N.S & 1.55 & 0.07 & N.S \\
\hline $\mathrm{P} \times \mathrm{H}$ & N.S & 2.16 & N.S & 21.49 & N.S & N.S \\
\hline $\mathrm{W} \times \mathrm{H}$ & N.S & 2.03 & N.S & N.S & N.S & N.S \\
\hline $\mathrm{P} \times \mathrm{W} \times \mathrm{H}$ & N.S & 3.46 & N.S & 2.71 & N.S & N.S \\
\hline
\end{tabular}

Data in Table (3 and 4) show that ear characters (length; diameter; number of grains / row; total weight; grains weight and shelling percentage were significantly decreased by increasing plant population up to 28000plants / feddan in both seasons . However number of rows/ear was significantly in second season only. This may be attributed to the high competation between plants for light, water, and minerals . These results were in agreement with those obtained by Abd-El-Samie (2001). Data in Table (1) show that grain yield per feddan was significantly increased by increasing plant population up to 23333 plants / feddan. These results may be due to that the high population densityresulted in great numberof stand at harvesting and this may compensate the decrease in grain weight / plant of high population similar results were reported by Abuzar et al,.(2011).

Regard to weed control treatment effect the data indicated that significant differences were observed among weed control treatment for all characters i.e. ( plant height, ear height, number of ear per plant ,ear length ,ear diameter , number of rows per ear , number of grains per row ,ear weight, grain weight per ear, seed index , shelling $\%$ and grain yield / feddan). In both seasons and data revealed that using hand hoeing twice increased maize yield and yield components. Similar findings were reported by Abouziena, et al (2008) found that the highest yields of maize were obtained by hoeing two times during the growing seasons. The effect of maize hybrids on all characters, (plant height, ear height , number of ear per plant ,ear length ,ear diameter , number of rows per ear , number of grains per row ,ear weight, grain weight per ear, seed index , and grain yield / feddan) were significant in both seasons. While shelling \% significant affected by maize hybrids in second season only

Fayoum J. Agric. Res. \& Dev., Vol. 31, No.2, July, 2017 
F.S.Abd-El-Samie., et al.,

. The superiority was for Neffertiti 3 and TWC 310 hybrids in most characters . But TWC1100 recorded the lowest value.

Table (3): Effect of plant population and weed control treatments on some ear characters of some maize hybrids in 2012 and 2013 seasons.

\begin{tabular}{|c|c|c|c|c|c|c|c|c|}
\hline \multirow{2}{*}{$\begin{array}{c}\text { Treatment } \\
\text { Season } \\
\end{array}$} & \multicolumn{2}{|c|}{ Ear length (cm) } & \multicolumn{2}{|c|}{ Ear diameter $(\mathrm{cm})$} & \multicolumn{2}{|c|}{ Row number/ear } & \multicolumn{2}{|c|}{$\begin{array}{c}\text { Grains number } \\
\text { /ear }\end{array}$} \\
\hline & 2012 & 2013 & 2012 & 2013 & 2012 & 2013 & 2012 & 2013 \\
\hline \multicolumn{9}{|c|}{ Plant Populations: } \\
\hline 28000 plants/ fed. & 17.24 & 15.53 & 5.94 & 6.01 & 11.73 & 11.39 & 24.29 & 24.56 \\
\hline 23333 plants / fed. & 17.54 & 17.82 & 6.07 & 6.19 & 12.12 & 11.70 & 25.59 & 25.43 \\
\hline 20000 plants / fed. & 18.02 & 19.63 & 6.12 & 6.32 & 12.19 & 12.12 & 26.31 & 31.60 \\
\hline LSD & 0.168 & 0.345 & 0.033 & 0.034 & N.S & 0.125 & 0.922 & 0.256 \\
\hline \multicolumn{9}{|c|}{ Weed Control: } \\
\hline Hoeing (one) & 17.62 & 17.49 & 6.06 & 6.13 & 12.11 & 11.78 & 25.64 & 26.40 \\
\hline Hoeing (two) & 18.32 & 19.84 & 6.19 & 6.49 & 12.13 & 12.02 & 26.48 & 31.49 \\
\hline Unweeded & 16.86 & 15.64 & 5.88 & 5.89 & 11.79 & 11.41 & 24.07 & 23.71 \\
\hline LSD & 0.167 & 0.165 & 0.034 & 0.036 & 0.212 & 0.096 & 0.221 & 0.206 \\
\hline \multicolumn{9}{|c|}{ Maize Hybrids: } \\
\hline TWC 310 & 17.00 & 17.77 & 5.90 & 6.06 & 12.10 & 11.67 & 25.55 & 26.53 \\
\hline TWC 1100 & 17.46 & 16.30 & 6.05 & 6.17 & 11.82 & 11.50 & 24.15 & 26.24 \\
\hline TWC Nefertiti 3 & 18.33 & 18.90 & 6.18 & 6.28 & 12.11 & 12.04 & 26.49 & 28.82 \\
\hline LSD & 0.142 & 0.165 & 0.042 & 0.029 & 0.247 & 0.083 & 0.632 & 0.249 \\
\hline \multicolumn{9}{|c|}{ LSD $5 \%$ interaction : } \\
\hline $\mathrm{P} \times \mathrm{W}$ & N.S & 0.433 & N.S & 0.565 & N.S & 0.163 & 0.903 & 0.345 \\
\hline $\mathrm{P} \times \mathrm{H}$ & 0.237 & 0.367 & N.S & N.S & N.S & N.S & N.S & 0.400 \\
\hline $\mathrm{W} \times \mathrm{H}$ & N.S & 0.327 & .0 .520 & 0.060 & N.S & 0.146 & N.S & 0.398 \\
\hline $\mathrm{P} \times \mathrm{W} \times \mathrm{H}$ & N.S & 0.574 & N.S & 0.044 & N.S & 0.253 & N.S & 0.687 \\
\hline
\end{tabular}

Table (4) : Effect of plant population and weed control treatments on some ear characters of some maize hybrids in 2012 and 2013 seasons.

\begin{tabular}{|c|c|c|c|c|c|c|c|c|}
\hline \multirow{2}{*}{$\begin{array}{l}\text { Treatment } \\
\frac{\text { Season }}{}\end{array}$} & \multicolumn{2}{|c|}{ Ear weight (g) } & \multicolumn{2}{|c|}{$\begin{array}{l}\text { Grains weight } \\
\text { (g) / ear }\end{array}$} & \multicolumn{2}{|c|}{$\begin{array}{l}100 \text { grain } \\
\text { weight }(g)\end{array}$} & \multicolumn{2}{|c|}{ Shelling \% } \\
\hline & 2012 & 2013 & 2012 & 2013 & 2012 & 2013 & 2012 & 2013 \\
\hline \multicolumn{9}{|c|}{ Plant populations: } \\
\hline 28000 plants/ fed. & 101.36 & 99.75 & 74.83 & 75.33 & 27.07 & 26.49 & 73.74 & 75.07 \\
\hline 23333 plants / fed. & 108.70 & 105.70 & 84.93 & 83.97 & 27.92 & 27.77 & 78.14 & 78.94 \\
\hline 20000 plants / fed. & 112.03 & 141.40 & 89.24 & 114.58 & 28.81 & 29.67 & 79.66 & 80.68 \\
\hline LSD & 4.974 & 2.939 & 3.200 & 2.434 & 0.396 & 0.521 & N.S & 951 \\
\hline \multicolumn{9}{|c|}{ Weed Control: } \\
\hline Hoeing (one) & 108.04 & 111.83 & 88.58 & 116.80 & 28.06 & 27.79 & 77.76 & 78.000 \\
\hline Hoeing (two) & 114.44 & 144.66 & 96.52 & 141.82 & 28.94 & 30.84 & 78.20 & 80.50 \\
\hline Unweeded & 99.60 & 90.36 & 82.62 & 85.10 & 26.80 & 25.30 & 75.58 & 76.18 \\
\hline LSD & 1.942 & 1.819 & 1.544 & 1.628 & 0.183 & 0.291 & 1.094 & 0.389 \\
\hline \multicolumn{9}{|c|}{ Maize Hybrids: } \\
\hline TWC 310 & 110.64 & 113.91 & 85.22 & 88.80 & 28.43 & 28.09 & 76.72 & 77.37 \\
\hline TWC 1100 & 95.49 & 103.36 & 74.32 & 81.49 & 25.86 & 26.46 & 77.67 & 78.24 \\
\hline TWC Nefertiti 3 & 115.95 & 129.58 & 89.46 & 103.58 & 29.50 & 29.38 & 77.16 & 79.08 \\
\hline LSD & 2.668 & 1.678 & 1.823 & 1.417 & 0.347 & 0.235 & N.S & 0.329 \\
\hline \multicolumn{9}{|c|}{ LSD $5 \%$ interaction : } \\
\hline $\mathrm{P} \times \mathrm{W}$ & N.S & 3.419 & 3.388 & 2.942 & N.S & 0.580 & N.S & 0.968 \\
\hline $\mathrm{P} \times \mathrm{H}$ & 5.495 & 3.330 & 3.622 & 2.781 & N.S & N.S & N.S & 0.946 \\
\hline $\mathrm{W} \times \mathrm{H}$ & 4.150 & 2.893 & 2.926 & 2.495 & 0.516 & 0.426 & N.S & 0.585 \\
\hline $\mathrm{P} \times \mathrm{W} \times \mathrm{H}$ & N.S & 5.178 & N.S & 4.413 & N.S & 0.787 & N.S & 1.197 \\
\hline
\end{tabular}

Fayoum J. Agric. Res. \& Dev., Vol. 31, No.2, July, 2017 
Data in Table (1) indicated that there was a significant interaction between plant population and weed control treatments on grain yield / feddan in second season only, as well as other interactions between all treatments in this study.

\section{REFERENCES}

Abd-El- Samie, F.S (2000). Efficiency of metribuzin application methods in five maize varieties . Proc.9th Conv., Minufiya Univ., 1-2 Sept. 2000: 211222.

Abd-El-Samie, F.S (2001). Effect of plant population density and weed control on growth and yield of maize crop and its associated weeds. Minufiya J. Agric. Res. 26. (1):85-98.

Abouziena, H.F., M.A. Ahmed, M.A.T. Eldabaa and M.S.A. Abd El Wahed (2013). A Comparative Study on the Productivity of Maize Cultivars Grown Under Various Weed Control Management Middle. East J. Agric. Res., 2(2): 56-67.

Abuzar, M. R., G. U. Sadozai, M. S. Baloch, A. A. Baloch, I. H. Shah, T. Javaid and N. Hussain (2011). Effect of plant population Densities on yield of maize the J.animal \& plant Sci, 21(4) : 692-695..

Alias.M.A, H. A. Bukhsh, R. Ahmad, A. U. Malik, S. Hussain and $\quad$ M. Ishaque, (2010). Agro-physiological traits of three maize hybrids as influenced by varying plant density The J. Animal \& Plant Sci. 20(1): 34-39.

Amare.T, A. Mohammed., M. Negeri, and F. Sileshi, (2015). Effect of weed control methods on weeed density and maize (zea mays 1.) yield in West Shewa Orimia, Ethiopia African J. plant Sci academicjournals $.9(1) .8-12$.

Aryannia.N, M.R. Enayatgholizadeh, and M. Sharafizadeh, (2013). Response of grain yield and yield components of two grainy maize hybrids to plant density and natural weeds. Population Australian J. Basic and Applied Sci. 7(2) : 590-597.

Atta.Y.I.M.(2014).Improving growth, yield and water productivit of some maize cultivars by new planting method innovativeWater Management Award winning Paper:1-12.

Bandy.B.J (2014). Response to planting density for corn hybrids grown under narrow and conventional row spacing Thesis University of Illinois at Urbana-Champaign. .

El-Metwally, E. A.; A.A. El-Deeb, S.A. Safina, and B.G. Rabbani, (2011). Behavior of some maize hybrids cultivated with different plant densities. J. Plant Production, Mansoura Univ.2 (3): 479 - 490.

El-Metwally, I.M., .M.S. Abd El-Salam, R.M.H. Tagour, and H.F. Abouziena ( 2012). Efficiency of plant population and reduced herbicides rate on

Fayoum J. Agric. Res. \& Dev., Vol. 31, No.2, July, 2017 
maize productivity and associated weeds J.Applied Sci. Res. 8(4): 23422349.

Farnia,A. and M. Mansouri (2014). Effect of plant density to yield and yield components of maize (Zea mays L.) cultivars bull. Env. Pharmacol. Life Sci. 3 [Special Issue V]: 123-127.

Gomez, KA. Gomez AA (1984). Statistical procedures for agricultural research. $2^{\text {nd }}$ Ed. An International Rice Research Institute Book. John Wiley and Sons pp. 321- 323, 467-469.

Kandil, E.E E. ( 2014). Determine independent population density for each maize hybrid (Zea Mays L.) Intl. Conference on Agric. and Biotechnology IPCBEE. 79:30-35.

Kandil, E.E.E. and .A.M. Kordy (2013). Effect of hand hoeing and herbicides on weeds, growth, yield and yield components of maize (Zea Mays L.) J.Applied Sci. Res.9(4): 3075-3082.

Mahdi, A.H.A. and S.K.A. Ismail (2015). Maize productivity as affected by plant density and nitrogen fertilizer. Int. J.Curr. Microbiol. App. Sci 4(6): 870-877.

Poole, M. L. and G.S. Gill (1987). The use of weed density-crop yield relationships for predicting yield loss in the field. Proc. $\mathrm{Br}$. Crop Prot. Conf. Weeds 3: 945-954.

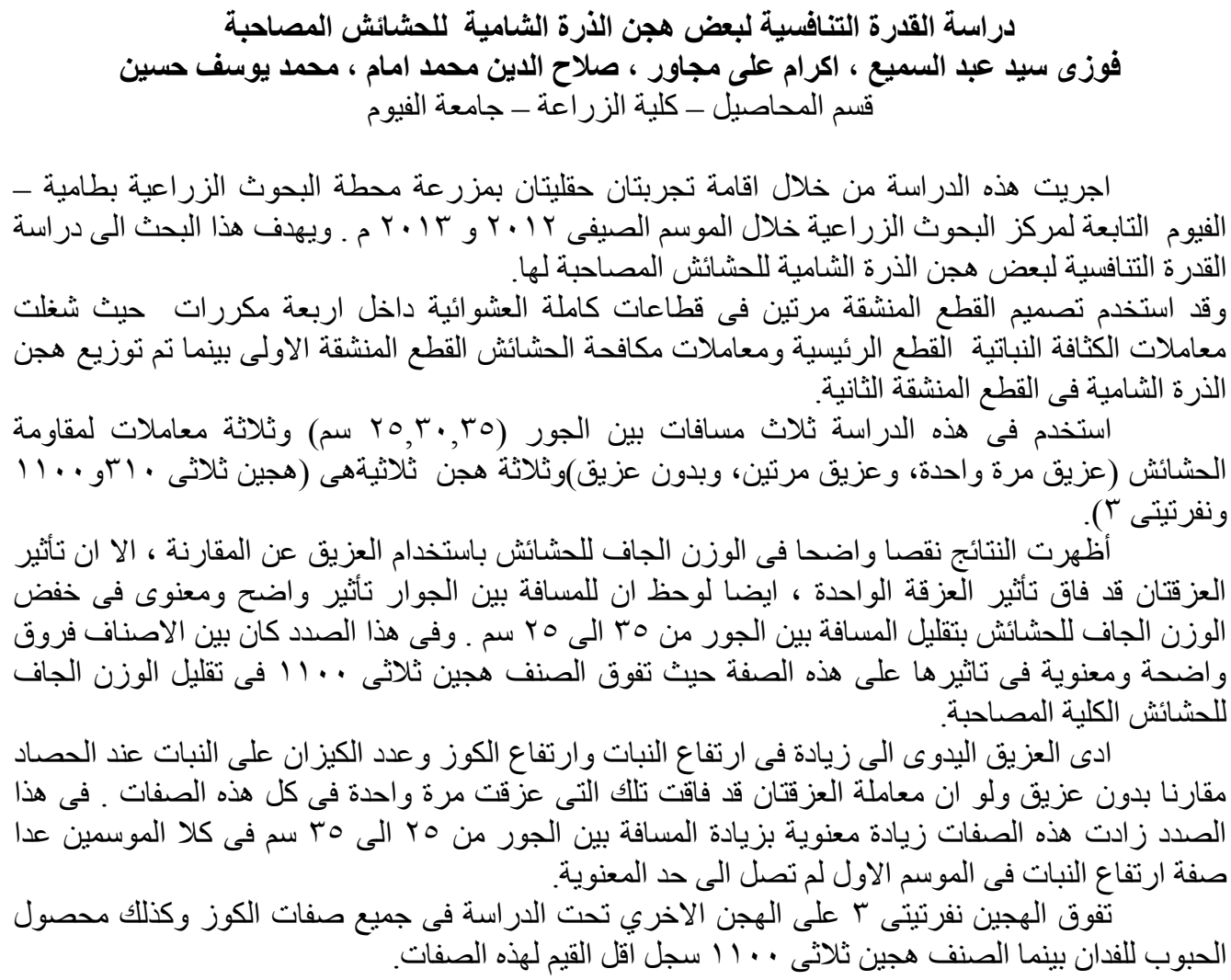

Fayoum J. Agric. Res. \& Dev., Vol. 31, No.2, July, 2017 